\title{
Presentation of Mathematics Object in Verbal and Symbolic Forms to Increase Conceptual Understanding in Category Statistics Math
}

\author{
Ahmad Yani $\mathrm{T}^{1)}$, Lucius Chih-Huang Chang ${ }^{2)}$ \\ Universitas Tanjungpura, Pontianak, Indonesia \\ E-mail:dr.ahmad.yani@gmail.com \\ National University of Kaohsiung, Taiwan, R.O.C \\ E-mail: chchang@nuk.edu.tw
}

\begin{abstract}
This study aims to obtain objective information about the presentation of mathematical objects in the form of verbal and symbolic to improve the conceptual understanding and interest in student learning after being given a lesson with the presentation of mathematical objects in the form of verbal and symbolic in the Mathematical Statistics Course Semester VI Mathematics Education Study Program PMIPA FKIP University of Tanjungpura Pontianak The sample of this research is the fourth semester students who follow the Basic Mathematics course of Mathematics Education program of PMIPA FKIP for the academic year 2016-2017. Data collection is done by giving test result of learning after given treatment. The essay-like test is 10 questions. The result of the research shows that there is an increase of students' learning result through presentation of mathematical object in verbal and symbolic form to improve conceptual understanding in Mathematics Statistics Semester VI Mathematics Education Study Program and there is an increase of learning interest after given learning by presentation of mathematical object in verbal and symbolic form.
\end{abstract}

Keywords: Mathematical Objects in Verbal and Symbolic Form; Conceptual Understanding; Procedural Understanding

\section{INTRODUCTION}

One reason children do not like math is the way the teacher teaches. Most teachers teach without variation or monotonous (Kennedy and Tipps, 1994). This causes the process of learning mathematics class is not interesting and boring. The inability of teachers in managing the class to run well due to the mastery of teachers on teaching materials, especially related to the idea/ideas of mathematics is less. The teacher's lack of understanding of these ideas causes the teacher to be unable to properly develop the learning to the students. Because teachers only deliver material based on textbooks (textbooks).
In the process of learning in the classroom, ideally, teachers are able to develop both conceptual and procedural knowledge with a balanced proposition (Munaldus, et al, 1998). This means that the delivery of ideas by teachers in learning can use various ways tailored to the purpose of learning mathematics. In lectures (Mathematics Statistics course) students have not been able to distinguish conceptual understanding with procedural understanding. In terms of presentation of mathematical objects of SMP and SLTA more emphasis on conceptual understanding. Because the presentation of ideas from mathematics can be expressed in various ways namely verbal (semantic) and symbolic and figural (picture). 
Based on the objectives of mathematics subjects junior (Kemendikbud, 2013) states that in learning mathematics students are expected to have the ability to understand the concepts and procedures of mathematics. NCTM (2000: 11) states "students must learn mathematics by understanding, actively building new knowledge from prior experience and knowledge" (Nurul, 2016).

Mathematics learning that oriented to the objectives and nature, the implementation in front of the class is not enough to equip students with a variety of mathematical knowledge but more than that required a real effort done intensively. According to Walle (2008: 13), the learning of mathematics is often done more focused on the job of finding or getting answers, applying mathematical formulas directly, and following the procedures used by teachers. If the problem continues to be ignored then the possibility of students will not be successful in learning mathematics.

Mathematics learning at every level of education refers to two main objectives, namely formal goals and material goals (Soedjadi, 1992: 8). The formal purpose of learning mathematics is the purpose related to the arithmetic of reasoning and the formation of learners' attitudes, while the objective of mathematical learning materials is the purpose related to the use and application of mathematics, both in mathematics itself and other fields. For the arrangement of reason as a benchmark the ability of students to understand the definition and theorem, whether presented in verbal sentences (words), pictures (figural) or in symbolic form. Meanwhile, the essence of mathematics education (Sumarmo, 2002: 22) has two directions of development, namely development for the needs of the present and the future. The development of today's needs is the learning of mathematics leading to an understanding of the concepts necessary to solve other mathematical and scientific problems. While the needs in the future is a mathematical learning that provides the ability to reason and logical, systematic, critical, and careful and objective and open thinking.

Based on the objectives needed to build a conceptual understanding is the knowledge of ideas that have existed and developed by making a logical connection between these ideas. Thus, students can develop concepts and procedures into other forms of representation, provide logical reasons for the concepts and procedures that are being developed, and can choose the concepts and procedures appropriate and efficient to solve the problems at hand.
Therefore, in the learning of mathematics (lectures), it is required the students' ability to develop ideas/ideas in understanding a concept. In the mathematics education program of PMIPA FKIP Untan, there are courses that become the basis for developing the logical arrangement, namely the mathematics course, Opportunity and Differential Equations.

The fact of the field shows that the conceptual and procedural capabilities and understanding of mathematical ideas or ideas are still relatively weak. The weakness is due to (1) lack of understanding of symbols in mathematics, (2) the mastery of the material is still weak, (3) less able to understand the meaning of a mathematical idea or idea, (4) less able to apply the formula in solving the problem. In addition, there are factors that are internal, among others, less accustomed to discuss or express opinions in class. This weakness resulted in some courses which are continuing difficulties, such as Micro Teaching (PPL-1) and Field Experience Practice (PPL).

\section{Presentation of Idea-Ideas in Mathematics}

In general, students who take Mathematics Statistics courses have difficulty developing their reasoning ability. Due to studying the subjects of mathematical statistics, each student requires a complete knowledge of the basic principles, probability of events, sample space, random changes and multiple opportunity distributions, mathematical expectations and moment generating functions, conditional probabilities and, opportunities with random variables. Thus, students are able to master and apply and apply the basic concepts of opportunity and its properties and able to use in solving related problems and problems related to the concept of expectations of two random variables.

In addition, understanding of definitions and theorems is an obstacle for students to interpret both the proof and its application in solving the problem. According to Guilford (in Yani, A, 2002), there are four categories used to convey or accept an idea, namely: (1) Figural (Model), (2) Semantics (Verbal or words), (3) Symbolic and (4) Behavioral behavior. For the Behavioral category is not discussed in this study, as it is difficult to understand. While the three categories are generally used to present or communicate ideas/ideas in mathematics. In the presentation of ideas/ideas (definitions and theorems) in mathematics can be started from Figural, Semantic and symbolic or semantic, figural and symbolic or otherwise.

Of the three categories (figural, semantic, and symbolic) difficult to present is to write a 
mathematical concept (definition or theorem) in symbolic form, because it takes several symbols to be agreed upon. Semantic categories are usually presented in textbooks (textbooks), especially in high school and high school and figural levels usually in primary education (primary and junior high). Given the wide range of Mathematics Statistics course, research emphasizes conceptual and procedural understanding. Because conceptual and procedural understanding is concerned with school math materials. Therefore, each student must master conceptual and procedural understanding as a provision for teaching mathematics in high school.

Permendikbud Number: 58 Year 2014 About Curriculum 2013 SMP / MTs discusses conceptual understanding in the purpose of learning mathematics in school. One of the objectives of mathematics in school is so that learners can understand the concept of mathematics with the indicators of achievement of the skills, among others:

- Redefine the concept learned

- Identify the nature of the operation or concept

- Apply the concept logically

- Presents the concept in various forms of mathematical representation.

- Associate various concepts in mathematics as well as outside mathematics.

- Developing the necessary terms and / conditions is quite a concept

While NAEP (2002) states that students demonstrate a conceptual understanding of mathematics, if students provide evidence it can:

- Recognize and apply facts and definitions.

- Uses and links the diagrams, models, manipulatives, and representations of various concepts.

- Identify and apply the principles

- Compare and integrate related concepts and principles to develop concepts and principles

- Interpret and apply the signs, symbols, and terms used for the development of concepts and create relationships involving concepts in mathematics.

Conceptual and Procedural Understanding

\begin{tabular}{lccc}
\multicolumn{1}{c}{ In } & this & presentation & conceptual \\
understanding & also & includes & procedural \\
comprehension. & Thus & if using & conceptual \\
understanding & means & there is & procedural
\end{tabular} understanding. Conceptual understanding is an understanding of the concepts, operations, and relationships of both in learning mathematics (NCTM, 2000: 5). Kilpatrick and Swafford (2001: 118) suggest that conceptual understanding refers to the understanding of integrated and functional mathematical ideas. Students organize their knowledge into a coherent whole, allowing them to learn new ideas by connecting ideas they already know. While Walle (2008: 29) with different terms states that conceptual knowledge as a collection of ideas that together and there is a relationship between these ideas. Therefore conceptual understanding is an understanding of integrated and functional mathematical objects used to solve problems by using certain steps. Conceptual understanding in this research is the ability of students in understanding the objects of mathematics, in the form of verbal and symbolic with the steps as follows:

- Redefine the concept that has been learned.

- Give an example or not an example of a learned concept.

- Presents the concept into verbal, visual and symbolic representations.

Presentation of Mathematical Objects in Verbal and Symbolic Form

In mathematics, schools are known terms with mathematical objects. Mathematical objects are divided into two direct objects and indirect objects. Direct objects include facts, concepts, principles, and skills. Indirect objects, among others, are: (1) the timing to perform theorem proof, (2) the ability to solve problems, (3) the ability to work individually and (4) have a positive attitude. (Amin, S., 2004). In this research is the presentation of mathematical objects in the form of verbal and Symbolic is the use of symbols of mathematical logic or words to understand in solving and solving problems.

For the presentation of mathematical objects using symbolic required steps as follows.

- Read definitions and theorems carefully to capture the meaning of each statement (single statement).

- Sorting out compound statements (definitions or theorems) into several single statements.

- Write a logical hyphen word used in compound statements and other words.

- Determine symbols relevant to the logic and other words.

- Write a single statement with symbol form

- Merge single statements that have been written with symbols based on the hyphen and other words specified.

(Yani, A., 1999: 2)

Application of symbols-Symbols of Logic in writing Definitions and Theorems

NCTM (Hulukati, 2005) suggests that mathematical communication (read "writing definitions and theorems in symbolic form") is the student's capabilities include: 
- Read and write mathematical ideas/ideas and interpret the meanings and ideas of the writing,

- Express and explain their thinking about mathematical ideas and their relationships,

- Formulate the definition of mathematics and make generalizations encountered through investigation,

- Write a mathematical presentation with

Class Pretest Treatment Posttest

\begin{tabular}{llll} 
Experiment & $\mathrm{T}$ & $\mathrm{X}_{\mathrm{A}}$ & $\mathrm{T}$ \\
\hline
\end{tabular}

understanding,

- Using vocabulary/language, structural notation of mathematics to present the idea of describing relationships, and modeling,

- Understand, interpret and assess ideas presented orally, in writing or in visual form,

- Observe and make conjectures, formulate questions, collect and assess information, and

- Generate and present convincing arguments.

For the ability to write definitions and teams in symbolic form in the broad sense of changing the compound statements of definitions and theorems by using mathematical symbols, figural symbols (figures), and semantics (words). So that visible understanding and ability of student in understanding idea/idea of the math. Understanding a written mathematical presentation, making a single revelation, formulating arguments, formulating definitions and teams in symbolic.

From some of the above opinions, it can be concluded that the ability to write the definition and the theorem by using symbolic include two things namely the ability to reason as expression in the form of symbolic (mathematical model), and creativity that required creative thinking that includes lateral and divergent thinking. So it looks like the ability of students to express the concept (definition or theorem) of mathematics by declaring daily events in language or mathematical symbols (called: "Mathematical Expression").

\section{RESEARCH METHOD}

The research method used in this research is experimental method. Suryabrata (2000: 29) states, "The purpose of experimental research is to investigate the possibility of causal intercourse by means of wearing a particular treatment to one or more experimental groups". This experimental method is used because it is in accordance with the purpose of research that is to determine the improvement of conceptual understanding (learning outcomes) of students after being given treatment.
The form used in this study is quasi-experimental. This form of study was chosen because the researcher did not have the ability to control or manipulate all the relevant variables such as student learning interest, intelligence level, and family economic background of each student. (Suryabrata, 2000: 33). The research design used is Only Posttest Control Group Design (Suryabrata, 2000: 35) with the design chart as follows:

Table I

Research Design

Keterangan:

$\mathrm{T}=$ Test

$\mathrm{X}_{\mathrm{A}}=$ Presentation of Mathematical Objects in VerbalSymbolic Form

\section{RESULT AND DISCUSSION}

Before testing the hypothesis then tested normality. This is done to determine the statistics used hypothesis testing. To test the normality of data from samples used Chi-Square test. Here is a table of normality test results:

\begin{tabular}{ccc}
\multicolumn{3}{c}{$\begin{array}{c}\text { Table II } \\
\text { Normality Test Results }\end{array}$} \\
\hline $\begin{array}{c}\text { Variation } \\
\text { Source }\end{array}$ & Pre-test & Post-test \\
\hline Total & 132 & 183 \\
\hline $\mathrm{N}$ & 30 & 30 \\
\hline $\bar{X}$ & 4,4 & 6,10 \\
\hline Varians $\left(\mathrm{s}^{2}\right)$ & 1,56 & 2,23 \\
\hline $\begin{array}{c}\text { Deviation } \\
\text { Standard }\end{array}$ & 1,25 & 1,49 \\
\hline
\end{tabular}

From $\mathrm{F}$ test results obtained $\mathrm{F}_{-}$hitung and F_tabel. Since the value F_count <F_table is 1.43 $<1.85$ then H_0 is rejected, it means that both data variance is homogeneous. Furthermore, t-test of one group to test the hypothesis.

\begin{tabular}{cc} 
Table III \\
\multicolumn{2}{c}{ Recapitulation Result of Test $\mathrm{t}$} \\
\hline $\mathrm{Df}$ & 29 \\
\hline $\mathrm{Md}$ & 1,7 \\
\hline $\mathrm{T}_{\text {statistics }}$ & 0,34 \\
\hline $\mathrm{T}_{\text {table }}$ & 1,70 \\
\hline
\end{tabular}

From the calculation results obtained that $\mathrm{t}$ count $<$ ttabel is $0.34<1.70$. Thus Ho with significant $\alpha=0.05$ is rejected and Ha accepted. So it can be concluded that there is an increase in pre-test and post-test results in writing the definition of the 
symbolic into the form of verbal (words) and vice versa.

The data of students' learning interest was obtained from comparing the pretest and post-test results. Based on the above table obtained information that there is an increase between the results of pre-test and post-test. Therefore it can be seen also the interest of learning after being given pre-test so that the values obtained increasing.

About pre-test is given to 30 students, obtained data as follows

Table IV

Comparison of Pretest and Posttest Results

\begin{tabular}{ccccc}
\hline Category & $\begin{array}{c}\text { Pre } \\
\text { Test } \\
\text { Score }\end{array}$ & Percentage & $\begin{array}{c}\text { Post } \\
\text { Test } \\
\text { Score }\end{array}$ & Percentage \\
\hline Low & 15 & $50 \%$ & 1 & $3,33 \%$ \\
\hline Medium & 15 & $50 \%$ & 25 & $83,33 \%$ \\
\hline High & 0 & $0 \%$ & 4 & $13,33 \%$ \\
\hline
\end{tabular}

Table 4 shows that the results of pre-test in writing the definition of symbolic into verbal form (words) and vice versa have a balance between low and medium category that is 15 students or $50 \%$ of all students who follow the pre-test. While the posttest results in writing the definition of the symbolic into the verbal form (words) is dominated by the medium category that is as many as 25 students or $83.33 \%$ of all students who follow post-test.

After the analysis, the researcher can conclude that there is an increase of pre-test result and post-test in writing the definition of symbolic into verbal form (words) and vice versa. This is probably due to:

- The average initial test score (pre-test) is lower than the average value of the final test result (post-test) which is caused before the initial test question the student has not understood the meaning of the symbol that will be changed into the verbal form (word- words).

- The average value of the final test result (posttest) is higher than the average pre-test score which is caused before the final test question of some students already understand the meaning of symbols that will be changed into verbal form ( words).

Based on the results of pre-test and post-test that have been given information that there is an increase in student learning interest in writing the definition of the symbolic into the form of verbal (words) and vice versa. This can be seen from the increasing of pre-test and post-test. In the pre-test results obtained are still quite balanced between the categories of medium and low while the post-test showed an increase that most of the students included in the category of being. Based on the analysis of the answers note that students experience increased interest in learning from pretest and post-test. The result of pre-test is low because it is caused by some things like less accustomed to write the definition of symbolic into verbal form (words) and vice versa, not yet comprehend the meaning of symbols in mathematics while after being given learning by presentation of mathematical object in verbal and symbolic form about writing the definition of the symbolic into the verbal form (words) and vice versa and how to understand the meaning of symbols in mathematics, students become interested in doing post-test which is indicated by the increasing result from pre-test result. Therefore it can be concluded that in addition to experiencing an increase in the value of pretest and posttest results, students also experience interest in learning after being given a lesson with the presentation of mathematical objects in the form of verbal and symbolic.

\section{CONCLUSIONS}

1. There is an increase in student learning outcomes through the presentation of mathematical objects in the form of verbal and symbolic to improve conceptual understanding in the course of Mathematical Statistics Semester VI Mathematics Education Studies Program.

2. There is an increase in interest in learning after being given a lesson with the presentation of mathematical objects in the form of verbal and symbolic.

\section{REFERENCES}

Amin, S . (2014). Sistem Deduktif Aksiomatis Dalam Matematika dan Matematika Sekolah

Arikunto, Suharsimi. (2002). Dasar-dasar Evaluasi Pendidikan. Jakarta: Bumi Aksara. Jakarta: Bina Aksara.

Husna, Nurul (2016) Pengembangan Bahan Ajar Berbasis Multirepresentasi Untuk Meningkatkan Pemahaman Konseptual dan kelancaran Prosedur Matematis Siswa Di Sekolah Menengah Pertama, Tesis Magister Pendidikan Matematika FKIP Untan: Tidak Dipublikasika.

Kennedy, L.M., \& Tipps, S.(1994). Guiding children's learning mathematics (fifth edition). New York: Macmilan. 
Klipatrick, Jeremy \& Jane Swafford (2001) Adding It Up, Helping Children Learn Mathematics, Washington DC: Mathematics Learning Study Committee.

Munaldus, Mirza, A., Yani, A.(1998). Analisis terhadap pengetahuan konseptual dan prosedural dalam buku paket matematika sekolah dasar. Penelitian Dosen Muda yang dibiayai Dikti. Pontianak: FKIP UNTAN

NAEP.(2002). National Assessment Governing Board. Washington, DC: U.S Government Printing Office.

Nawawi, H. (2005). Instrumen Penelitian Bidang Sosial. Yogyakarta: Gadjah Mada University Press.

NCTM (2000) Principles And Standards For School Mathematics, U.S: NCTM

Sudjana, Nana. (1999). Penilaian Hasil Proses Belajar Mengajar. Bandung : Remaja Rosdakarya.Bandung: Tarsito.

Suryabrata, Sumadi. (2000). Metodologi Penelitian. Jakarta: Raja Grafindo Persada.

Walle, John A.(2008). Matematika Sekolah Dasar dan menengah (Pengembangan

Pengajaran. Jakarta: Erlangga.

Yani A., (2002). Penyajian Gagasan Matematika Dengan Menggunakan Cara Figural, dan Semantik serta Simbolik. Makalah di sajikan Dalam Konferensi Nasional Matematika XI di Malang tanggal 2125 Juli 2002 dan dimuat dalam Jurnal Matematika atau Pembelajaran Tahun VIII, Edisi Khusus, Juli 2002, 349-354 Malang: Universitas Negeri Malang (UNM).

Yani, A, dkk,.(1999). Pelatihan Menulis Definisi dan Bukti Teorema Dengan Mengguna-kan Simbolik. (Proyek, Heds Ditjen Dikti Depdikbud Tahun Anggaran 1999/2000). Pontianak: Fakultas MIPA Untan Pontianak.

Yani, A., dan Lanteri C (2017) Implementation of Reciprocal Teaching Model to Increase The Capability of Writing Definition and Theorem in Symbolic Form, Journal of Education Teaching and Learning: Volume 2 Number 1 March 2017, Page 81-85. 